\title{
High-resolution image analysis of laminae (organic-rich with calcareous nannofossils) in a black shale sequence: probability of orbital and suborbital climate cycles in the latest Cenomanian
}

\author{
Jong-Gwon Yum ${ }^{1}$, Philip A. Meyers ${ }^{2}$, Theodore C. Moore ${ }^{2}$, Yulee $\mathrm{Kim}^{1 *}$ \\ ${ }^{1}$ E\&P Technology Department, Korea National Oil Corporation \\ ${ }^{2}$ Marine Geology and Geochemistry Program, The University of Michigan
}

\begin{abstract}
We conducted a high-resolution image analysis of the lamination present in a core interval of black shale from Hole 1260B (ODP Leg 207) on the Demerara Rise in the western tropical Atlantic. Gray scale digital image analysis results revealed environmental cyclic patterns that could be related to orbital and suborbital changes during the latest Cenomanian $(94 \mathrm{Ma})$. High-resolution nannofossil biostratigraphy provided the detailed chronological information needed to constrain the time intervals of each cyclic event. A study of thin sections showed that the basic pattern of the millimeter-scale laminae was couplets of alternating dark organic-rich layers and white biogenic test layers. The composition of the dark organic-rich layer appeared to include the remains from microbial organisms with a chain-like structure. From the combination of the gray scale and thin section analyses, three well-expressed cyclic patterns could be recognized in the black shale interval, namely (1) meter-scale cyclic events (average interval of approximately $413 \mathrm{~mm}$ ), (2) centimeter-scale cyclic events (approximately 10-30 mm intervals), and (3) millimeter-scale cycles (average interval of approximately $5 \mathrm{~mm}$ ). These cyclic events could imply approximately $40 \mathrm{ky}, 1-3 \mathrm{ky}$, and 300-700 yr time spans, respectively, on the basis of biostratigraphy. In addition, two other cyclic patterns indicating approximately $20 \mathrm{ky}$ and 60-150 yr time intervals were weakly expressed.
\end{abstract}

Keywords: gray scale analysis, orbital cycles, laminae, Cenomanian, black shale

\section{Introduction}

The mid-Cretaceous (Cenomanian-Turonian) was a time of peak global greenhouse climate conditions with the highest sea level, highest $\mathrm{CO}_{2}$ concentration in the atmosphere, and low thermal gradients from the poles to the equator. Distinctly laminated black shales, which are dark-colored mudstones enriched in total organic carbon (e.g. Ohkouchi et al., 2015), are common features of mid-Cretaceous organicrich sediments. These intervals of black shale deposition are often referred to as Oceanic Anoxic Events (OAEs) and are considered to be representative of times of black shale formation during Earth history (Ohkouchi et al., 2015). How the laminated black shales were deposited remains an open debate (e.g. Negri et al., 2003; Meyers, 2006; Jansa and Xiumian, 2009). Although millennial-scale cyclicity of black shales during this period has been described from continental outcrops or cores (Kuhnt et al., 1997; Kuroda et al., 2005), similar detailed descriptions from the deep sea are rare. Hetzel et al. (2011) observed that such cyclic patterns could be interpreted to present climatically induced changes in sediment supply, whereas Minisini et al. (2015) presented a process sedimentology of lamination in black shales from the Eagle Ford Formation. These limestone and marlstone couplets reflect climatic forcing driven by solar insolation, such as obliquity and precession etc. Oppositely, a driving mechanism of small-scale cyclicity in black shale was reported by Owens et al. (2016), which showed that the cyclothemic lamination in black shale was probably induced by quasi-periodic climate fluctuations.

Laminated sediment sequences provide important information about the conditions of deposition, including factors such as hydraulic dynamics and bioturbation (Kemp, 1996). Image analysis of laminated sediments is a particularly effective tool for high-resolution paleoenvironmental studies with the additional benefit of low cost (Francus et al., 2004). However, since the first application of image analysis to laminated core sediments (Ripepe et al., 1991; Abouelresh, 2014), there has been no detailed description of millimeterscale lamination of black shales related to the driving

Manuscript received September 12, 2018; Revised October 24, 2018; Accepted October 24, 2018.

*Corresponding author: Yulee Kim, Tel: +82-52-216-3509, Fax: +82-52-216-5946, E-mail: yulee.kim@knoc.co.kr

(C) 2018 Korean Society of Petroleum and Sedimentary Geology

This is an Open Access article distributed under the terms of the Creative Commons Attribution Non-Commercial License (http://creativecommons.org/licenses/by-nc/4.0/) which permits unrestricted non-commercial use, distribution, and reproduction in any medium, provided the original work is properly cited. 
mechanism. Here, we applied high-resolution image analysis to a sequence of micro-laminated late Cenomanian black shale in order to assess whether the laminations have different orders of cyclicity (decadal to tens of millennia), which may imply orbital and suborbital climate cycles.

\section{Samples and Analysis}

\subsection{Geology Setting of Site 1260}

The Demerara Rise is a submarine plateau off the coast of Suriname that stretches northward and gently dips to the northwest (Fig. 1). Early Cretaceous faulting along the northwestern edge of the Demerara Rise was caused by extensional movements, and created the gently dipping ramp that reaches up to $4,000 \mathrm{~m}$ of water depth (Gouyet et al., 1994; Benkhelil et al., 1995). The Demerara Rise was drilled at Site 1260 (Leg 207, 2,549 m below the present sea level) in 2003. Lithologic descriptions of this site reveal a relatively continuous sedimentary Oligocene to early Albian succession with only a few hiatuses (Erbacher et al., 2004). The midCretaceous paleolocation of the site was in the equatorial region. A $93 \mathrm{~m}$ thick Coniacian-Albian sequence of Site 1260, which included the sample of this study, consisted almost exclusively of laminated black shale (Erbacher et al., 2004). We chose a $4 \mathrm{~m}$ sediment interval from a late Cenomanian sequence with no diastem. Based on shipboard observations, laminations associated with granulated foraminiferal layers may reflect changes in carbonate productivity, episodic winnowing, or grain flows (Erbacher et al., 2004).

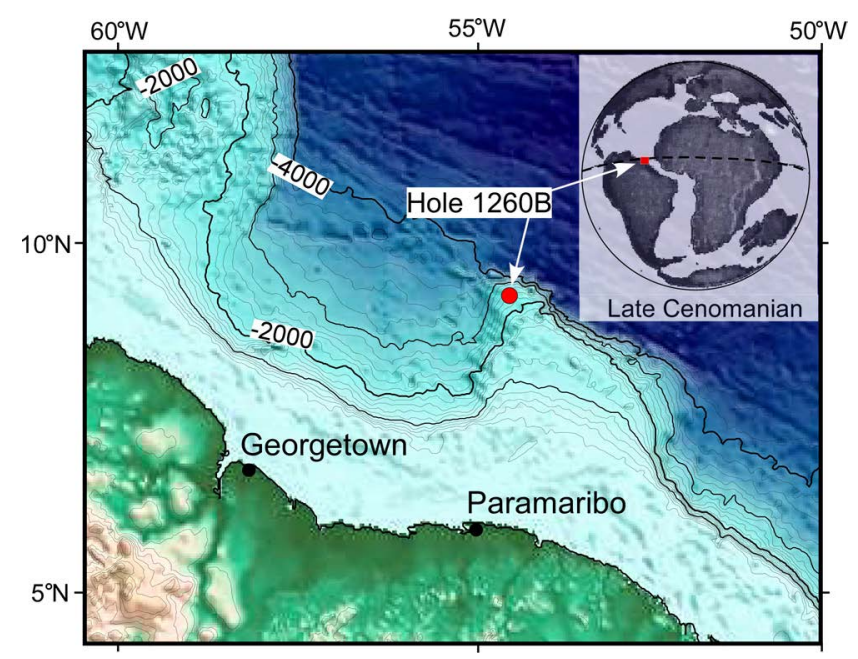

Fig. 1. Location of Hole $1260 \mathrm{~B}$ on the Demerara Rise and its late Cenomanian paleoposition.

\subsection{Image Analysis}

We selected a 4 m length (428.25-432.37 mod of Hole 1260B) of drilling core sample for the high-resolution lamina study. One-quarter diameter of the well-laminated sediment core interval was cut from the core at the ODP Bremen Core Repository and stabilized in clear plastic shrink wrap for transport to our laboratory in Michigan. The intervals were separated to approximately $0.3-0.8 \mathrm{~m}$ length along natural breaks in the laminae. The core samples were not fully lithified, so they were carefully treated and opened just before analysis. The first step of our analysis was to take high-quality digital photographs under uniform exposure conditions. Before placing the sample on a camera stand table similar to that of Schaaf and Thurow (1994), artificial features, such as saw or scratch marks, were eliminated by smoothing the surface with a scalpel. The core sample was moved in a down-core direction on a simple parallel conveyer system that was made from a commercial aluminum frame. One-third image overlap was used to minimize edge-image distortion. Each image therefore covered an approximately $25 \mathrm{~mm}$ interval of the core sample. The series of images were merged together carefully using the image editing software Adobe Photoshop. We applied ImageJ 1.33u (e.g. Abramoff et al., 2004) to extract the gray scale variation from the final image. For diminution of high-frequency noise within the gray scale values (Cooper, 1997), a smoothing method was applied.

In order to analyze the details of the millimeter-scale laminations, resin-impregnated thin sections (Boës and Fagel, 2005) were prepared. A microscope with a digital camera was applied to capture the magnified image. We applied the same process to extract gray scale variation from the thin section image.

\subsection{Biochronology}

High-resolution calcareous nannofossil biostratigraphy provided the detailed chronological information needed to constrain the time intervals of laminae features. Hardas and Mutterlose (2005) established a detailed biostratigraphic framework from a $10 \mathrm{~cm}$ interval sampling for the CenomanianTuronian Boundary Interval (CTBI) in Hole 1260B. Based on the first and last occurrences of the biostratigraphically important nannofossil taxa (FO: G. segmentatum; LO: $G$. thera), Hole 1260B 428.5-432.7 mod interval could be assigned to the UC3b-UC3d nannofossil zone (Burnett, 
1998), which also corresponded to biozone NC12 (FO of $G$. segmentatum at 447.79 mcd; FO of $Q$. gartneri at 425.54 mcd) of Roth (1978). Based on Burnett's nannofossil zonation, the sedimentation rate in the sample range was estimated to be approximately $11.05 \mathrm{~mm} / \mathrm{ky}$ (Gradstein et al., 1995; Hardas and Mutterlose, 2005). Based on the NC biozone of Roth (1978), it could also be calculated as approximately $11.12 \mathrm{~mm} / \mathrm{ky}$ around the target period. In addition, the shipboard results suggested an average sedimentation rate of approximately $9 \mathrm{~mm} / \mathrm{ky}$ for the Cenomanian-Coniacian section of Site 1260 (Erbacher et al., 2004). From the good agreement of these three different biochronological estimates, we assumed the sedimentation rate of the sample interval to be between 9 and $11.12 \mathrm{~mm} / \mathrm{ky}$, or approximately $10 \pm 1$ $\mathrm{mm} / \mathrm{ky}$.

\section{Results}

\subsection{General Description of Gray Scale Profiles}

We recognized four different orders of cyclicity from the image analysis of Hole 1260B, namely (1) meter scale, (2) centimeter scale, (3) millimeter scale, and (4) basic laminae. Excluding meter scale, the lamination cycles were remarkably apparent in the transition from dark to bright color (Fig. 2). The reason for this may have been that strongly bright or dark parts of the core could not reveal the cyclic features that could be detected by image analysis. However, the fact that there was no visual cyclicity on the extreme parts did not mean that there were no inner-compositional cycles. Thus, clear cyclicity could remain a critical condition only during the time of intensive orbital activity. Nevertheless, we should realize the benefit of image analysis in that the cyclic trends unrecognizable to the naked eye can be detected. In contrast, some of the linear texture (possibly lamination) recognized by eye did not show a clear change in the image analysis. This phenomenon could have occurred because of the high-frequency optical noise that originated from the high-resolution digitizing. Therefore, a smoothing method to diminish this noise, such as the moving average command in Microsoft Excel, was applied to show any cyclicity more clearly (Cooper, 1997).

\subsection{Cyclicity and Possible Periods}

Above the critical gray value (around 80 gray scale), 10 sinuosity peaks were identified in the $4 \mathrm{~m}$ interval (Fig. 2).
These peaks define the meter-scale cycle that has an average wavelength of about $413 \mathrm{~mm}$. On the assumption that this cycle is associated with the $40 \mathrm{ky}$ obliquity cycle, the sedimentation rate could be deduced as $10.1 \mathrm{~mm} / \mathrm{ky}$, which agreed with the sedimentation rate of $10 \pm 1 \mathrm{~mm} / \mathrm{ky}$ calculated from the nannofossil analysis. In some cycles, small-scale peaks (Fig. 2) were located almost between the main meter-scale crests. These middle peaks may imply a weak effect from precession, which has a period of $22 \mathrm{ky}$. However, this cycle did not appear consistently through the entire interval.

White and clear laminae with intervals of approximately 10-30 mm (centimeter scale) were present throughout the core. The surface gray scale profile (Fig. 3a) represents this centimeter-scale cyclicity that clearly appeared among other millimeter laminae as the outstanding peaks that could be visually recognized (Fig. 3b). Around the traditional range of black and white (about 85 gray scale in Fig. 2), the centimeterscale cycle was more detectable. Although they had variable intervals between two peaks, most of the centimeter-scale peaks occurred at intervals between $10 \mathrm{~mm}$ and $30 \mathrm{~mm}$ and mainly had a length of approximately $15 \mathrm{~mm}$. Some of the peaks (Fig. 3b) were minor relative to other major peaks. Nevertheless, the retention of the same interval was continual. On the assumption that the sedimentation rate was $10.1 \mathrm{~mm} / \mathrm{ky}$, the centimeter-scale intervals implied an approximately 1-3 ky cyclic change.

Millimeter-scale laminae were the most significant feature among the different cyclicities (Fig. 4). Even though the millimeter-scale laminae appeared in most parts of the studied interval, they were more easily recognized in the transitions between the light and dark meter-scale cycles, which was similar to the centimeter-scale cycles. Faint millimeter-scale features at the core could be recognized clearly using image analysis (Fig. 4a and Fig. 4b) even though the more intense peak shapes (Fig. 4a) were more prominent in the image analysis. Peak intervals of millimeterscale range between $3 \mathrm{~mm}$ and $7 \mathrm{~mm}$ had an average interval of approximately $5 \mathrm{~mm}$. Increasing or decreasing trends of millimeter-scale intervals (e.g. Trend A of Fig. 4a) appeared in many parts of the $4 \mathrm{~m}$ interval. It seemed that the millimeter-scale intervals were related to progressive climate events that occurred at a period of 300 to $700 \mathrm{yr}$ based on the average sedimentation rate of $10.1 \mathrm{~mm} / \mathrm{ky}$. We do not have an explanation for these short-scale 
(a)

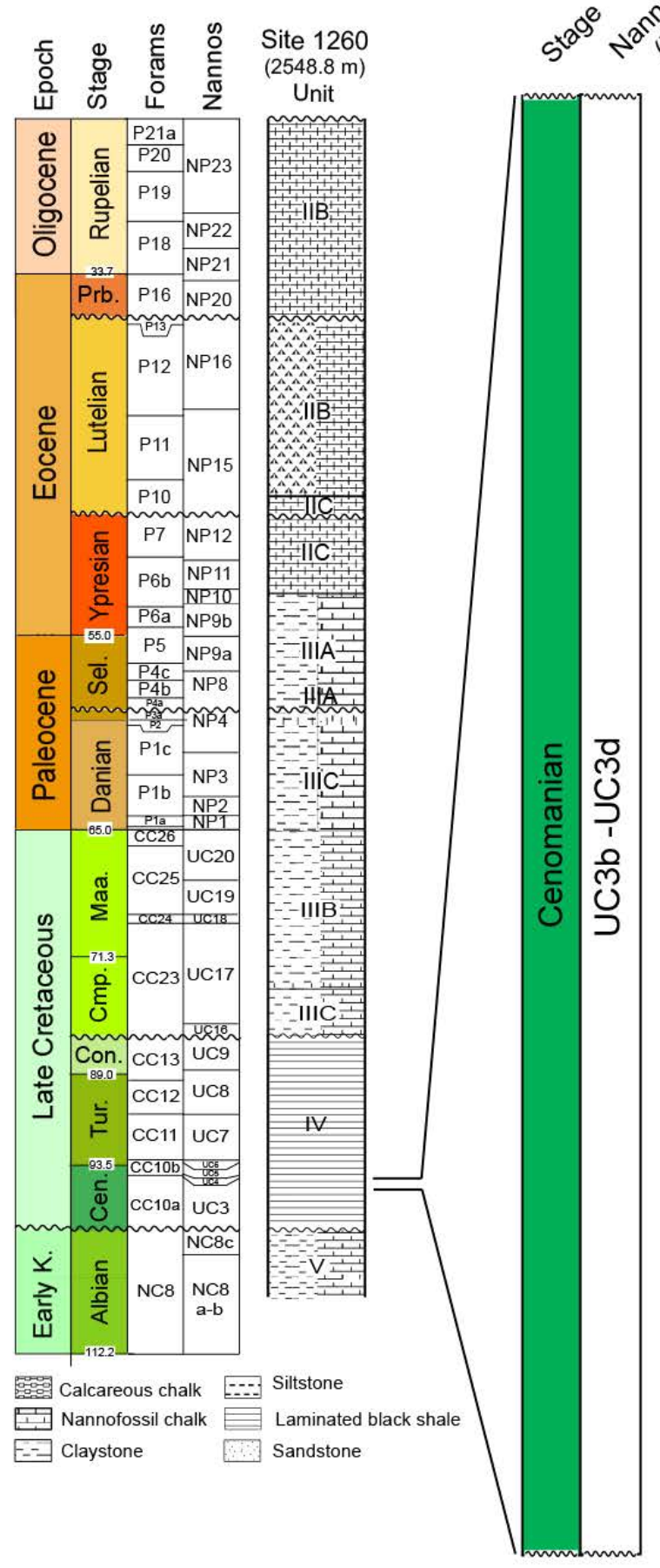

(b)<smiles>[O]C1CCCCC1CCCO</smiles>

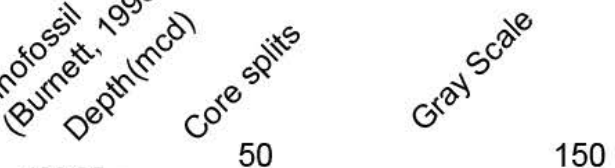

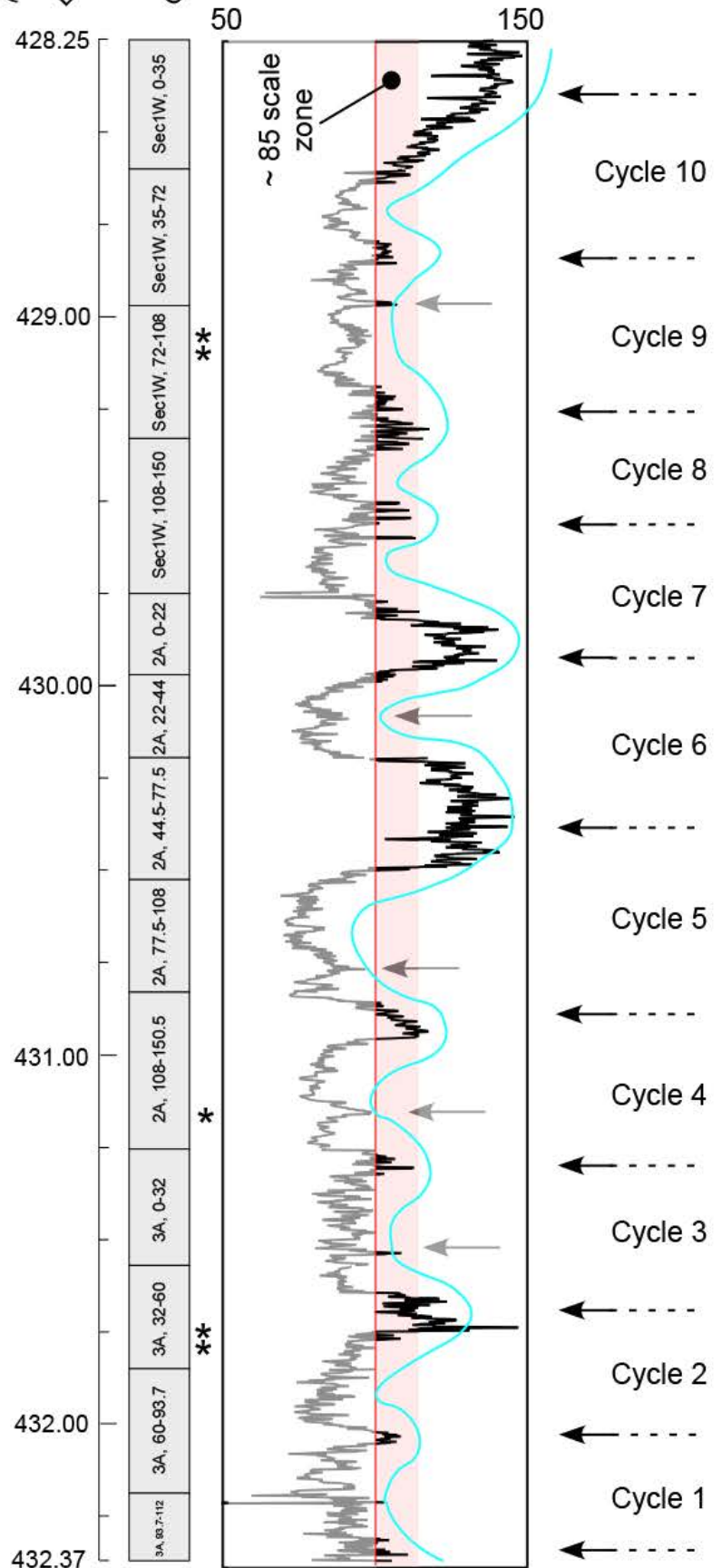

Fig. 2. (a) Stratigraphic location of the measured section (428.25-432.37 mcd of Site 1260B core; Erbacher and Shipboard Scientific Party, 2005). (b) Gray scale profile from the digitized images. About 10 sinuosity peaks are described, which may indicate a time interval of approximately $40 \mathrm{ky}$. The pale gray range (approximately 85 gray scale) indicates a well-laminated and measurable zone. ${ }^{*}$ indicates the location of the thin section.

variations, but they were similar to the century-scale variations reported by Kuroda et al. (2005) in the Livello Bonarelli Cenomanian-Turonian black shale sequence.
These relatively high-frequency cycles indicated that the depositional conditions leading to deposition of black shales was highly variable at times. 
(a)

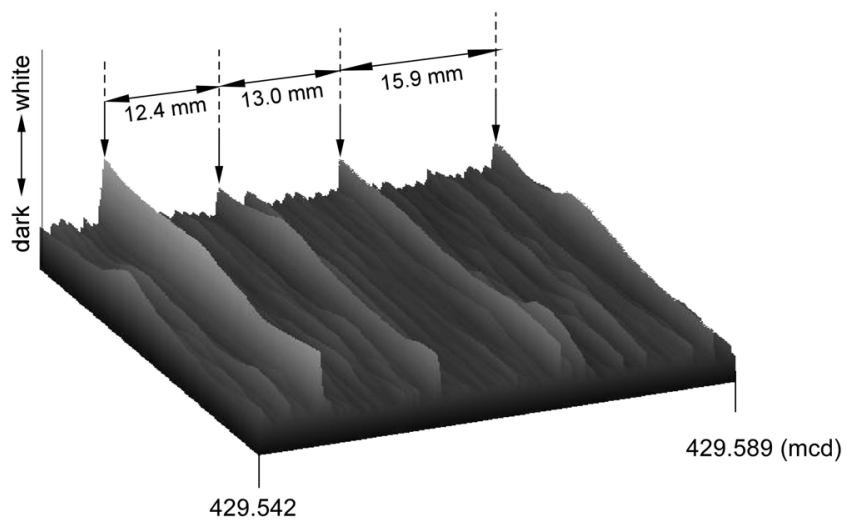

(b)

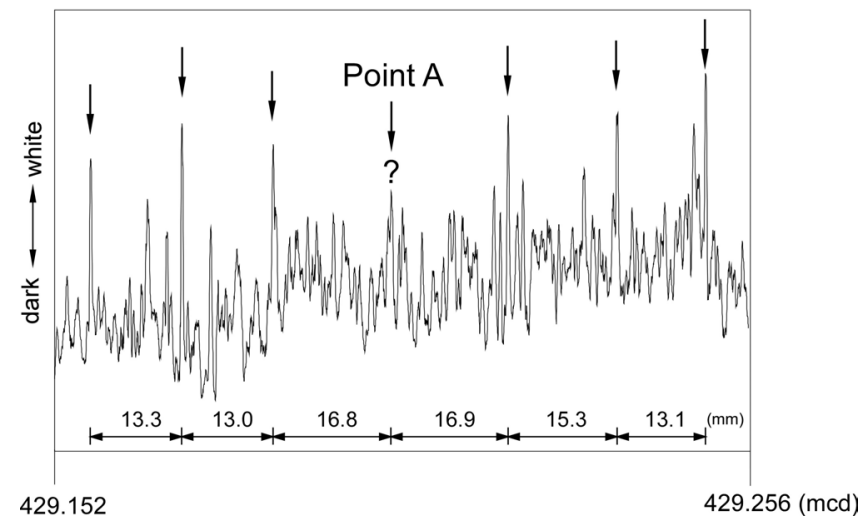

Fig. 3. Example of a centimeter-scale cycle, which may indicate an approximately 1-3 ky time interval. (a) Surface gray scale profile with smoothing option and (b) gray scale profile with smoothing option.
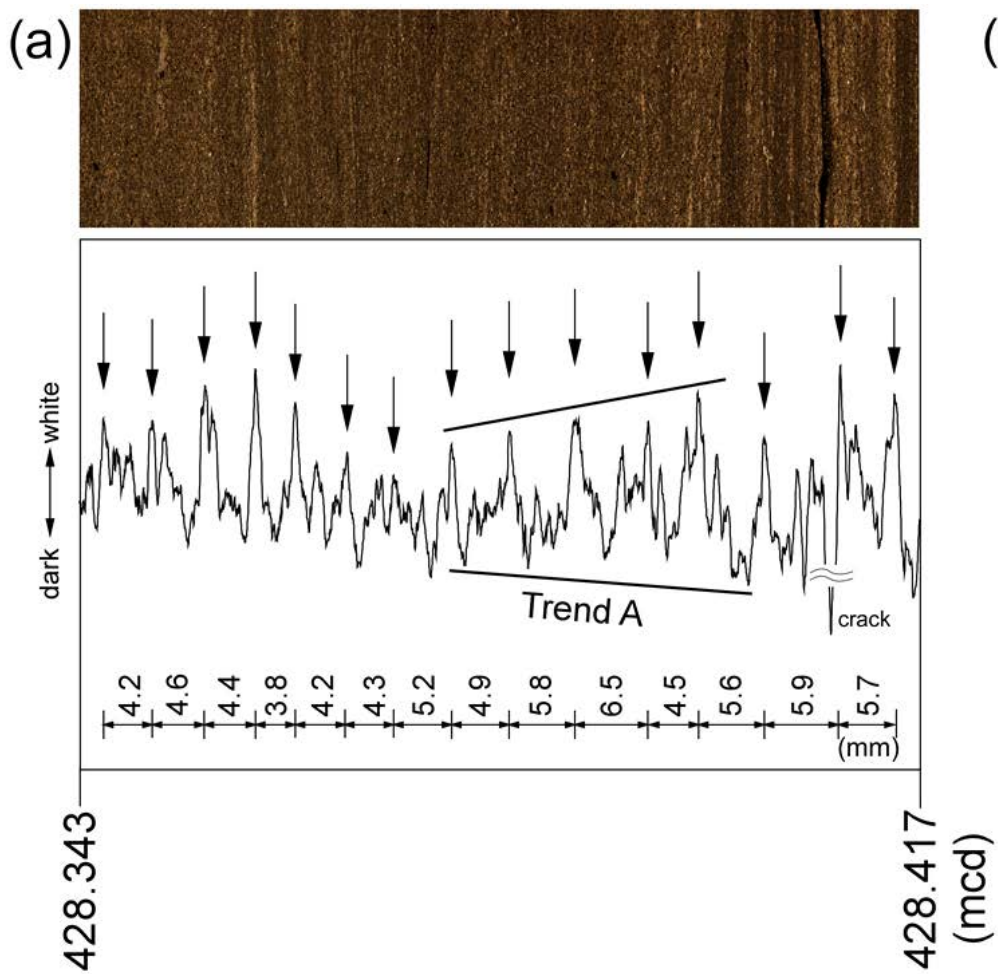

(b)
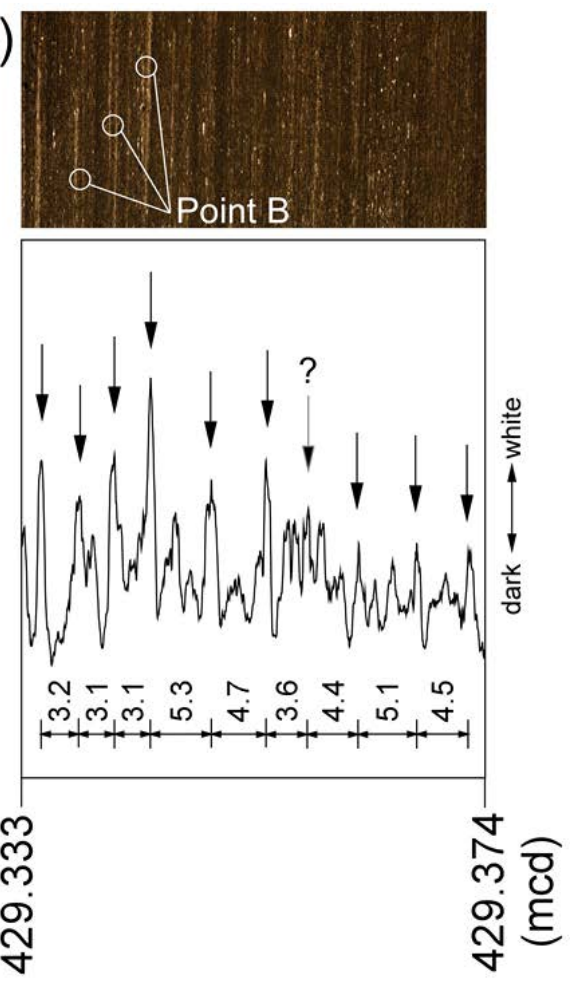

Fig. 4. Examples of a millimeter-scale cycle, which may indicate an approximately $300-700 \mathrm{yr}$ time interval. (a) Typical gray scale profile showing repeated cycles and (b) contrast of clear lamination (left) and less clear lamination (right).

Coupled laminae (Point B in Fig. 4b) appeared throughout the core interval and were especially associated with strongly expressed laminations. We inferred that the coupled laminae could be the basic unit of all lamination features. Examples of sequential basic laminae are shown in Fig. 5. The intervals between laminae ranged from $0.6 \mathrm{~mm}$ to $2 \mathrm{~mm}$. Obvious coupled laminae, such as those of Point B in Fig. 4b, had an approximately $0.6 \mathrm{~mm}$ interval, while sequential laminae, such as those in Fig. 5a, Fig. 5b, and Fig. 5c, were plotted from $1 \mathrm{~mm}$ to $1.5 \mathrm{~mm}$, which was the more common spacing through the core interval. Consequently, approximately 60$150 \mathrm{yr}$ could be considered the cyclic period of basic laminae. Increasing or decreasing trends of lamina intervals, such as those in Fig. 5b, appeared place by place. However, due to the limitation of thin section space, we could not define the existence of such trends everywhere. 


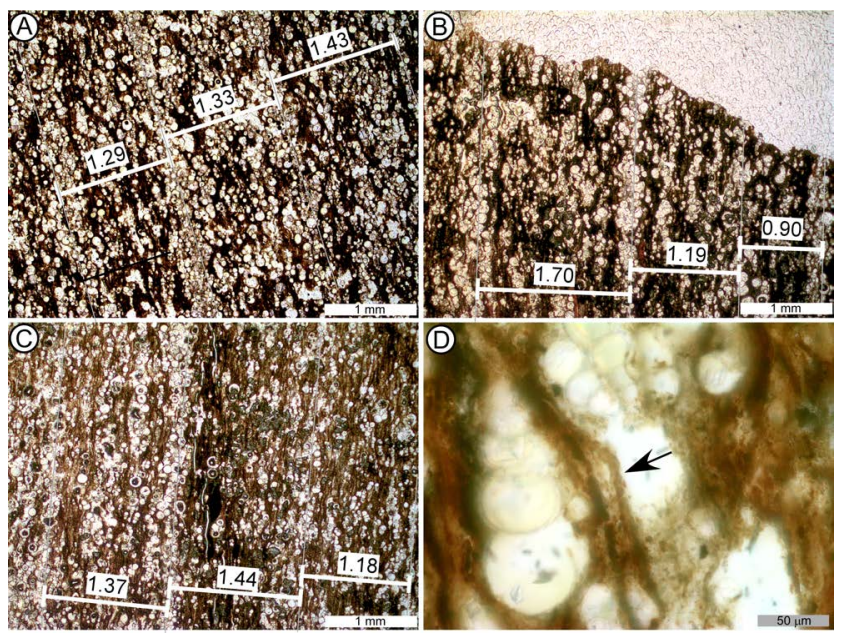

Fig. 5. Example photograph of each lamination, which may indicate an approximately 70-210 yr time interval. (a) Almost identical interval lamination, (b) increasing interval lamination, (c) crack developed in dark layer, and (d) possibility of microorganism composition in the matrix.

\subsection{Laminae Composition}

The microscopic images indicated that each lamina was created by the alternation of bright shells of planktonic organisms, such as foraminifers and radiolarians, and dark humic material that originated from organic matter. Observations of the thin section showed that sedimentation of the black shale sequence was quite stable without any disturbance and/or influx of secondary precipitation (Fig. 5). At the border where the planktonic shells and humic material met, we frequently found chain-like residues that may have been the remnants of microorganisms that were the origin of the humic material (Fig. 5d).

\section{Discussion}

\subsection{Significance of Laminated Sedimentation}

Two fundamental requirements demand for the development of a laminated sediment sequence. First, there must be variation in input, chemical conditions, or biological activity that will result in compositional changes in the sediment. Second, stable environmental conditions must exist to prevent the laminated sediment fabric from experiencing bioturbation or physical disturbance (Talbot and Allen, 1996). Therefore, the depositional environment of the micro-laminated black shale at Site 1260 should satisfy these conditions as well. Observations of the thin sections showed that bioturbation and/or strong diagenesis accompanied with calcite enrichment from the interstratal solution did not occur. Therefore, each lamina might preserve details of the depositional history during the mid-Cretaceous period that this sediment interval represented.

If an individual laminated couplet can be shown to represent sediment accumulation from a single year, then it is called a varve (de Geer, 1912). Classic varves comprise couplets of clastic sediment that differ in color and texture. Most varves occur in lake or offshore marine areas and originate from annual or seasonal depositional changes, but open ocean varved sequences also exist (e.g. Ripepe et al., 1991; Schimmelmann and Kastner, 1993). The oceanic varves usually indicate longer period cycles than annual accumulation, so the term varve is sometimes used for the wider meaning of any periodic sedimentary texture. The laminations identified in our study fell into the broader category of multi-annual varves that represent longer periodic cycles.

Multi-annual varves have been compared to long climatic cycles, such as El Niño (approximately 3-6 yr cycles; Hagadorn et al., 1995; Halfman and Johnson, 1988) or Earth orbital cycles. Kemp et al. (1996) tried to ascribe lamina-scale alternations in equatorial Pacific sediments to anti-El Niño (La Niña) periodicities as well, even though oceanic lamination environments still need to be better understood (e.g. Dean and Kemp, 2004). To the cyclicity of hundreds to several thousands of years, Anderson et al. (1987) attempted to describe the lamination-bioturbation facies in offshore California sediments. They deduced that the facies originated from the oscillation of the oxygen minimum zone (OMZ). Most studies that have focused on multi-annual varves have mainly been concerned with relatively recent climatic change, especially Milankovitch cycles during the Quaternary. The cyclic features of our study suggested the probability of these climatic cycles in the paleo-equatorial deep-sea environment.

\subsection{Mid-Cretaceous Orbital Cyclicity}

Although many cyclic studies do not focus only on laminated features, comparable studies of the Cretaceous cycle have described black shale sequences in both oceanic cores and continental outcrops. Herbert and Fischer (1986) showed clear evidence of Earth's orbital variations during the mid-Cretaceous. The $21 \mathrm{ky}$ cycle reflecting precession movement appears as repetitions of anoxic episodes and limestone marl from a black shale sequence in central Italy 
(Herbert et al., 1986). Another example of precession cycles during the Late Cretaceous was described by Martin-Chivelet and Gimenez (1992) from a lithostratigraphic study of the Sierra de Utiel Formation in southeast Spain. Wortmann et al. (1999) interpreted that the dominant periodicity of the lower Cretaceous sequence of the Rehbreingraben Formation in South Germany was related to the precession frequency as well. Milankovitch cycles of eccentricity (approximately $100 \mathrm{ky}$ ) were represented as the major periodicity in an upper Albian succession of the North German Basin by Prokoph and Thurow (2000). Fiet and Gorin (2000) assumed that cyclicity expressed by the pelagic marl and limestone alternations of Barremian deposits was the result of orbital parameters, especially precession and eccentricity. Hofmann et al. (2003) found millennial to centennial-scale cyclic records of Coniacian to Santonian deposits in the eastern tropical Atlantic. In particular, a high-resolution cyclostratigraphic framework allowed them to estimate a rapid change (within $\langle 1,000 \mathrm{yr}$ ) in black shale environmental conditions during this period. Similar evidence of shortterm changes for the Early Albian has been reported by Friedrich et al. (2005) as well.

For the Cenomanian, which was the target period of our study, some studies have presented evidence of orbital variation from outcrops of Cenomanian strata (Sageman et al., 1997; Gale et al., 2002). These previous results from Cretaceous black shales imply that Earth orbital variations may be the basis of our hypothesis that cyclicity of upper Cenomanian black shale of the Demerara Rise could also originate from orbital or suborbital movements. Furthermore, recent logging results from Cenomanian-Turonian black shale sequences in the Tarfaya Atlantic Coastal Basin in Morocco (Kuhnt et al., 2005) show similarities with our findings and suggest that these cyclic fluctuations (mainly obliquity) are general features of the Cenomanian to Turonian period. Moreover, results of the lamina-scale chemical compositional mapping of the Livello Bonarelli black shale by Kuroda et al. (2005) were more comparable with our results, which showed individual laminae at two different orders of fluctuations ranging from the $10^{2} \mathrm{yr}$ scale and the $10^{3}-10^{4}$ yr scale.

\subsection{Origin of Basic Lamina}

As mentioned in the previous sub-chapter, each lamina was created by the alternation of bright shells of planktonic organisms, such as foraminifers and radiolarians, and dark humic material that originated from organic matter.

The origin of high organic carbon contents in black shale deposited during the mid-Cretaceous is still debated. Part of the controversy is that high accumulation of organic matter in sediments under anoxic condition demands elevated primary production, which requires oceanic mixing that would yield more oxic and nutrient-rich conditions. However, recent studies have shown that the coupled presence of isorenieratene-derived biomarkers, which are distinctive to green sulfur bacteria, and low $\delta{ }^{15} \mathrm{~N}$ values, which are signals of nitrogen-fixing cyanobacteria (e.g. Ohkouchi et al., 2015), indicate that microbial primary productivity was important to black shale deposition and imply strongly stratified oceanic conditions (e.g. Kuypers et al., 2004; Meyers, 2006). Another study (Meyers et al., 2009) conducted with the same samples indicated that the same nitrogenfixing environment occurred in black shales during the mid-Cretaceous period. Consequently, the microbial organisms with a chain-like structure in the dark organic-rich layer could be deduced as Cyanobacteria. Here, we also inferred from the existence of laminae that primary productivity alternated between normal and strong stratified oceanic conditions during black shale deposition in response to the oscillation of orbital or suborbital change.

\section{Conclusions}

High-resolution image analysis of late Cenomanian black shale from Hole 1260B (ODP Leg 207) on the Demerara Rise suggested the following implications:

1) Gray scale digital image analysis results revealed environmental cyclic patterns that could be related to orbital and suborbital changes during the latest Cenomanian.

2) Three notable cyclicities were recognized in the late Cenomanian black shale, namely (1) meter-scale cyclic events (average interval of about $413 \mathrm{~mm}$ ), (2) centimeterscale cyclic events (approximately 10-30 mm intervals), and (3) millimeter-scale cycles (average interval of about $5 \mathrm{~mm}$ ).

3) These cyclic events could imply approximately $40 \mathrm{ky}, 1-3$ $\mathrm{ky}$, and 300-700 yr time spans, respectively, on the assumption that the sedimentation rate was approximately $10 \mathrm{~mm} / \mathrm{ky}$. In addition, two other cyclic patterns indicating approximately $20 \mathrm{ky}$ and 60-150 yr time intervals were 
weakly expressed.

4) Studies of thin sections showed that the basic pattern of the millimeter-scale laminae was couplets of alternating dark organic-rich layers and white biogenic planktonic shell layers. The composition of the dark organic-rich layer appeared to include the remains from microbial organisms with a chain-like structure, which were possibly Cyanobacteria.

\section{Acknowledgments}

This work was supported by the Korea Institute of Energy Technology Evaluation and Planning (KETEP) and the Ministry of Trade, Industry and Energy (MOTIE) of the Republic of Korea (No. 20152510101980).

\section{References}

Abouelresh, M.O., 2014, Core and petrographic sequential analysis of organic-rich shale. In: EAGE/SPE/AAPG Shale Gas Workshop in the Middle East. EAGE Publications BV, Netherlands (in process).

Abramoff, M.D., Magelhaes, P.J. and Ram, S.J., 2004, Image processing with imageJ. Biophotonics International, 11, 36-42.

Anderson, R., Hemphill-Haley, E. and Gardner, J.V., 1987, Persistent late Pleistocene-Holocene seasonal upwelling and varves off the coast of California. Quaternary Research, 28, 307-313.

Benkhelil, J., Mascle, J. and Tricart, P., 1995, The Guinea continental margin: an example of a structurally complex transform margin. Tectonophysics, 248, 117-137.

Boës, X. and Fagel, N., 2005, Impregnation method for detecting annual laminations in sediment cores: An overview. Sedimentary Geology, 179, 185-194.

Burnett, J.A., 1998, Upper cretaceous. In: Bown, P.R. (ed.), Calcareous Nannofossil Biostratigraphy. Chapman \& Hall, London, 132-199.

Cooper, M.C., 1997, The use of digital image analysis in the study of laminated sediments. Journal of Paleolimnology, 19, 33-40.

Dean, J.M. and Kemp, A.E.S., 2004, A 2100 year BP record of the Pacific Decadal Oscillation, El Nino Southern Oscillation and Quasi-Biennial Oscillation in marine production and fluvial input from Saanich Inlet, British
Columbia. Palaeogeography, Palaeoclimatology, Palaeoecology, 213, 207-229.

De Geer, G., 1912, A geochronology of the last 12,000 years. 11th International Geological Congress, Stockholm, 1910. Report 1, 241-253.

Erbacher, J. and Shipboard Scientific Party, 2004, Leg 207 Summary, Proceedings of the Ocean Drilling Program, Part A: Initial Reports. Ocean Drilling Program, Leg 207, Shipboard Scientific Party, College Station, Texas, USA, March 2014, 89 p.

Fiet, N. and Gorin, G., 2000, Lithological expression of Milankovitch cyclicity in carbonate-dominated, pelagic, Barremian deposits in central Italy. Cretaceous Research, 21, 457-467.

Francus, P., 2004, Image Analysis, Sediments and Paleoenvironments. Kluwer Academic Publishers, Dordrecht, Netherlands, $330 \mathrm{p}$.

Friedrich, O., Hichi, H., Pross, J., Schmiedl, G. and Hemleben, C., 2005, Millennial- to Centennial- Scale Interruptions of the Oceanic Anoxic Event 1b (Early Albian, mid- Cretaceous) Inferred from Benthic Foraminiferal Repopulation Events. PALAIOS, 20, 64-77.

Gale, A.S., Hardenbol, J., Hathway, B., Kennedy, W.J., Young, J.R. and Phansalkar, V., 2002, Global correlation of Cenomanian (Upper Cretaceous) sequences: Evidence for Milankovitch control on sea level. Geology, 30, 291294.

Gouyet, S., Unternehr, P. and Mascle, A., 1994, The French Guyana margin and the Demerara Plateau: geologic history and petroleum plays. In: Mascle, A. (ed.), Hydrocarbon and Petroleum Geology of France. Special Publication of the European Association of Petroleum Geoscientists, 4, 411 -422 .

Gradstein, F.M., Agterberg, F.P., Ogg, J.G., Hardenbol, J., Van Veen, P., Thiery, J. and Huang, Z., 1995, A Triassic, Jurassic and Cretaceous time scale. In: Geochronology, Time Scales and a Global Stratigraphic Correlation. SEPM Special Publications, 54, 95-126.

Hagadorn, J.W., Stott, L.D., Sinha, A. and Rinon, M., 1995, Geochemical and sedimentologic variations in interannually laminated sediments from Santa Monica Basin. Marine Geology, 125, 11-131.

Halfman, J.D. and Johnson, T.C., 1988, High resolution record of cyclic climatic change during the past $4 \mathrm{ka}$ from Lake Turkana, Kenya. Geology, 16, 496-500. 
Hardas, P. and Mutterlose, J., 2005, Biostratigraphy and paleoecology of the Cenomanian and Turonian of Site 1260 (Leg 207, Demerara Rise) based on calcareous nannofossils. IODP/ICDP Colloquium, Potsdam, March 14-16.

Herbert, T.D. and Fischer, A.G., 1986, Milankovitch climatic origin of mid-Cretaceous black shale rhythms in central Italy. Nature, 321, 739-743.

Herbert, T.D., Stallard, R.F. and Fischer, A.G., 1986, Anoxic events, productivity rhythms, and the orbital signature in a mid-cretaceous deep-sea sequence from central Italy. Paleoceanography, 1, 495-506.

Hetzel, A., März, C., Vogt, C. and Brumsack, H.J., 2011, Geochemical environment of Cenomanian - Turonian black shale deposition at Wunstorf (northern Germany). Cretaceous Research, 32, 480-494.

Hofmann, P., Wagner, T. and Beckmann, B., 2003, Millennialto centennial- scale record of African climate variability and organic carbon accumulation in the ConiacianSantonian eastern tropical Atlantic (Ocean Drilling Program Site 959, off Ivory Coast and Ghana). Geology, 31, 135138.

Jansa, L. and Xiumian, H., 2009, Cretaceous oceanic red beds; stratigraphy, composition, origins, and paleoceanography and palaeoclimatic significance. SEPM Special Publication, 91, 59-72.

Kemp, A.E.S., 1996, Laminated sediments as palaeo-indicators. Palaeoclimatology and Palaeoceeanography from Laminated Sediments, Geological Society, Special Publication, 116, vii-xii.

Kemp, A.E.S., Baldauf, J.G. and Pearce, R.B., 1996, Origins and palaeoceanographic significance of laminated diatom ooze from the eastern equatorial Pacific Ocean. In: Kemp, A.E.S. (ed.), Palaeoclimatology and Palaeoceanography from Laminated Sediments, Geological Society, Special Publication, 116, 243-252.

Kuhnt, W., Nederbragt, A. and Leine, L., 1997, Cyclicity of Cenomanian-Turonian organic-carbon-rich sediments in the Tarfaya Atlantic Coastal Basin (Morocco). Cretaceous Research, 18, 587-601.

Kuhnt, W., Luderer, F., Nederbragt, S., Thorow, J. and Wagner, T., 2005, Orbital-scale record of the late Cenomanian-Turonian oceanic anoxia event (OAE-2) in the Tarfaya Basin, Morocco. International Journal of Earth Sciences, 94 147-159.
Kuroda, J., Ohkouchi, N., Ishii, T., Tokuyama, H. and Taira, A., 2005, Lamina-scale analysis of sedimentary components in Cretaceous black shales by chemical compositional mapping: Implications for paleoenvironmental changes during the Oceanic Anoxic Events. Geochimica et Cosmochimica Acta, 69, 1479-1494.

Kuypers, M.M.M., van Breugel, Y., Schouten, S., Erba, E. and Damsté, J.S.S., 2004, $\mathrm{N}_{2}$-fixing cyanobacteria supplied nutrient $\mathrm{N}$ for Cretaceous oceanic anoxic events. Geology, 32, 853-856.

Martin-Chivelet, J. and Gimenez, R., 1992, Palaeosols in microtidal carbonate sequences, Sierra de Utiel Formation, Upper Cretaceous, SE Spain. Sedimentary Geology, 81, 125-145.

Meyers, P.A., 2006, Paleoceanographic and paleoclimatic similarities between Mediterranean sapropels and Cretaceous black shales. Palaeogeography Palaeoclimatology Palaeoecology, 235, 305-320.

Meyers, P.A., Bernasconi, S.M. and Yum, J.-G., 2009, 20 My of nitrogen fixation during deposition of mid-Cretaceous black shales on the Demerara Rise, equatorial Atlantic Ocean. Organic Geochemistry, 40, 158-166.

Minisini, D., Eldrett, J., Bergman, S.C., Schieber, J., Ma, C. and Lutz, B., 2015, Laminated black shales: Process Sedimentology at lamina scale: Examples from the Eagle Ford Formation, TX, USA. AAPG Annual Convention and Exhibition, Denver, Colorado, May 31-June 3.

Negri, A., Cobianchi, M., Luciani, V., Fraboni, R., Milani, A. and Claps, M., 2003, Tethyan Cenomanian pelagic rhythmic sedimentation and Pleistocene Mediterranean sapropels; is the biotic signal comparable? Palaeogeography, Palaeoclimatology, Palaeoecology, 190, 373-397.

Ohkouchi, N., Kurida, J. and Taira, A., 2015, The origin of Cretaceous black shales: a change in the surface ocean ecosystem and its triggers. Proceeding of Japan Academy, Ser.B91, 273-291.

Owens, H.L., Algeo, T.J. and Herrnann, A.D., 2016, Correlation and climatic origin of small-scale cyclicity in Upper Pennsylvanian cyclothemic black shales. Geological Society of America, Abstracts with Programs, 48, Paper No. 38-6.

Prokoph, A. and Thurow, J., 2000, Diachronous pattern of Milankovitch cyclicity in late Albian pelagic marlstones of the North German Basin. Sedimentary Geology, 134, 287-303.

Ripepe, M., Roberts, L.T. and Fischer, A.G., 1991, ENSO 
and sunspot cycles in varved Eocene oil shales from image analysis. Journal of Sedimentary Petrology, 61, $1155-1163$.

Roth, P.H., 1978, Cretaceous nannoplankton biostratigraphy and oceanography of the northwestern Atlantic Ocean. Initial Reports of the Deep Sea Drilling Project, 44, 731759.

Sageman, B.B., Rich, J., Arthur, M.A., Birchfield, G.E. and Dean, W.E., 1997, Evidence for Milankovitch periodicities in Cenomanian-Turonian lithologic and geochemical cycles. Western Interior U.S.A. Journal of Sedimentary Research, 67, 286-302.

Schaaf, M. and Thurow, J., 1994, A fast and easy method to derive highest-resolution time-series datasets from drillcores and rock samples. Sedimentary Geology, 94, 110.

Schimmelmann, A. and Kastner, M., 1993, Evolutionary changes over the last 1000 years of reduced sulfur phases and organic carbon in varved sediments of the Santa Barbara Basin, California. Geochimica et Cosmochimica Acta, 57, 67-78.

Talbot, M.R. and Allen, P.A., 1996, Lakes. In: Reading, H.G. (ed.), Sedimentary Environments: Processes, Facies and Stratigraphy, 3rd ed., Blackwell Science, Oxford, 83-124. Wortmann, E.G., Hesse, R. and Zacher, W., 1999, Majorelement analysis of cyclic black shales: Paleoceanographic implications for the Early Cretaceous deep western Tethys. Paleoceanography, 14, 525-541. 